\title{
Крайникова Д.А. \\ Влияние внеклеточных метаболитов лактобацилл на чувствительность планктонных культур и биопленок Gardnerella vaginalis к метронидазолу in vitro
}

Оренбургский федеральный исследовательский центр УрО РАН

(Россия, Оренбург)

doi: 10.18411/lj-04-2021-48

\section{Аннотация}

Проблема бактериальных биопленок в инфекционной патологии остается актуальной. Формирование биопленочных сообществ микроорганизмов - одна из основных стратегий выживания бактерий в организмах инфицируемых хозяев.

Обнаружено, что метаболиты лактобацилл и отдельные компоненты (пероксид водорода, лактат, сурфактанты) потенцируют антимикробную активность метронидазола в отношении культур Gardnerella vaginalis, находящихся в состоянии биопленки, при этом наибольшей активностью обладали пероксид водорода и сурфактанты.

Ключевые слова: биопленки, Gardnerella vaginalis, лактобациллы, метронидазол, сурфактанты, лактат

\section{Abstract}

The problem of bacterial biofilms in infectious pathology remains relevant. The formation of biofilm communities of microorganisms is one of the main strategies for the survival of bacteria in the organisms of infected hosts.

It was found that metabolites of lactobacilli and individual components (hydrogen peroxide, lactate, surfactants) potentiate the antimicrobial activity of metronidazole against biofilm cultures of Gardnerella vaginalis, with hydrogen peroxide and surfactants having the highest activity.

Keywords: biofilms, Gardnerella vaginalis, lactobacilli, metronidazole, surfactants, lactate

В настоящее время полагают, что 60-65 \% инфекционных заболеваний, прежде всего инфекций, связанных с оказанием медицинской помощи (ИСМП), обусловлены способностью их возбудителей существовать в форме биопленок. Значительная их часть приходится на долю хронических инфекций, причем более $50 \%$ - у людей с ослабленной иммунной системой.

В литературе широко обсуждается возможное участие пленкообразующих микроорганизмов в развитии соматической патологии: обострений язвенной болезни желудка и двенадцатиперстной кишки, болезни Крона, миокардитов, атеросклероза, бронхиальной астмы, диабета 1 типа, онкологических, кардиоваскулярных заболеваний.

Способность бактерий образовывать биопленки рассматривается в настоящее время как фактор их патогенности. Многие хронические инфекции, возникновение которых связано с применением медицинского имплантированного оборудования (катетеров, линз, искусственных клапанов сердца, протезов), характеризуются возможностью бактерий расти на поверхностях этих устройств в виде биопленок.

Бактерии в составе биопленки становятся труднодоступными для атаки факторов иммунной системы макроорганизма. Даже у практически здоровых людей иммунная система не справляется с инфекциями, ассоциированными с биопленками. Биопленочная инфекция редко устраняется иммунной системой хозяина. Иммунный ответ хозяина может даже стать причиной повреждения тканей самого хозяина, окружающих пораженный участок. 
Структура и свойства биопленок обеспечивают бактериям повышение устойчивости к антибиотикам и дезинфектантам. В некоторых случаях это объясняется непроницаемостью наружных структур биопленки для молекул антибактериальных веществ.

Матрикс биопленки связывает и инактивирует антибактериальные препараты, а также не пропускает их внутрь структуры биопленки. Повышенная устойчивость бактериальных клеток, входящих в состав биопленки, объясняется уменьшением их свободной поверхности за счет плотных контактов друг с другом и формированием особых бактерий, получивших название персистеров.

Материалы и методы.

В работе использовали 22 штамма Gardnerella vaginalis, идентифицированных на основании морфологических, культуральных и биохимических характеристик.

Нативные метаболиты лактобацилл и их отдельные компоненты (перекись водорода, сурфактанты, лактат) получали как описано ранее [1].

Ростовые характеристики микроорганизмов оценивались фотометрически по накоплению биомассы, способность образовывать биопленки по удерживанию кристаллического фиолетового [2]. Относительное количество и жизнеспособность бактерий определяли по восстановлению 3-(4,5-диметилтиазол-2-ил)-2,5-дифенилтетразолий бромида в формазан [3]. Определение минимальной ингибирующей концентрации метронидазола для планктонных культур микроорганизмов определялась по задержке роста тест-штаммов в жидкой питательной среде методом микроразведений [4]. Определение МИК метронидазола для микроорганизмов в биопленке определялась по изменению относительного количества и жизнеспособности бактерий по восстановлению 3-(4,5-диметилтиазол-2-ил)-2,5дифенил-тетразолий бромида в формазан.

Экспериментальные данные представлены как среднее значение по крайней мере трех независимых экспериментов со стандартным отклонением $(\mathrm{M} \pm \mathrm{SD})$. Для статистического анализа и проверки нормального распределения использовалось программное обеспечение GraphPad Prism 6.0. Нормальность распределения данных проверялась с помощью критерия Колмогорова - Смирнова. Для оценки различий использовали между контрольными и экспериментальными значениями использовали метод ANOVA. Порог статистической значимости был установлен как двустороннее значение $\mathrm{p}=0,05$.

Результаты и обсуждения.

Установлено, что и нативные метаболиты лактобацилл, и отдельные их компоненты, такие как пероксид водорода, лактат, сурфактанты снижают резистентность G. vaginalis в биопленках к метронидазолу.

МИК метронидазола в отношении культур в биопленках был значительно выше в сравнении с МИК для планктонных культур и составлял 5,54 $\pm 2,11$ и $0,83 \pm 0,26$ мкг\мЛ, соответственно $(\mathrm{p}<0,05)$.

Под влиянием лактата, содержащегося в лактобациллах, чувствительность G. vaginalis к метронидазолу возрастала и это сопровождалось уменьшением минимальной

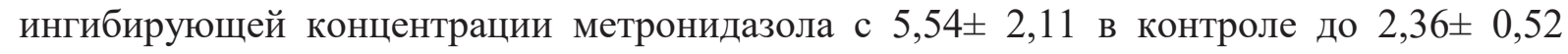
мкг\мл в пробах с лактатом $(\mathrm{p}<0,05)$.

Сурфактанты, выделенные из внеклеточных метаболитов лактобацилл также потенцировали антимикробное действие метронидазола в отношении гарднерелл. Так, под влиянием сурфактантов чувствительность G. vaginalis в биопленках к метронидазолу существенно возрастала, что сопровождалось уменьшением

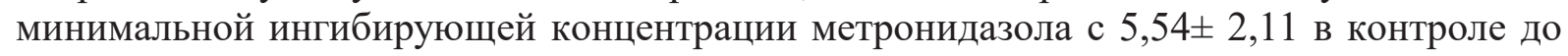
$1,42 \pm 0,33$ мкг \мл $(\mathrm{p}<0,001)$.

Пероксид водорода так же значительно увеличивал чувствительность G. vaginalis в биопленках к метронидазолу и это сопровождалось уменьшением 


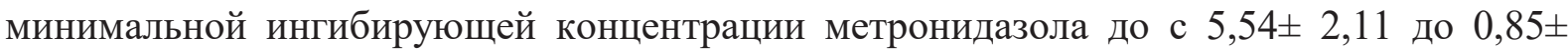
0,25 мкг \мл $(\mathrm{p}<0,001)$.

Следует отметить, что и нативные метаболиты лактобацилл также обладали способностью потенцировать антимикробный эффект метронидозола. Так, под влиянием нативных супернатантов пробиотического штамма L. casei subsp. rhamnosus Lcr35, который продуцирует и лактат и сурфактанты, чувствительность к метронидазолу у G. vaginalis в биопленках возрастала, и это сопровождалось уменьшением минимальной ингибирующей концентрации метронидазола до $1,34 \pm 0,37$ мкг \мл $(\mathrm{p}<0,001)$.

Таким образом, в нашем исследовании установлено, что внеклеточные метаболиты лактобациллы способны усиливать антибактериальные эффекты метронидазола в отношении культур Gardnerella vaginalis, находящихся в состоянии биопленки, при этом наибольшей активностью обладали пероксид водорода и сурфактанты.

Полученные данные расширяют наши представления о возможности использования представителей нормальной микрофлоры (лактобацилл) и отдельных компонентов их внеклеточных метаболитов для борьбы с биопленками, образованными условно-патогенными и патогенными микроорганизмами.

1. Sgibnev A., Kremleva, E. Influence of Hydrogen Peroxide, Lactic Acid, and Surfactants from Vaginal Lactobacilli on the Antibiotic Sensitivity of Opportunistic Bacteria. Probiotics \& Antimicro. Prot. 9, 131141 (2017). <https://doi.org/10.1007/s12602-016-9238-6>

2. O'Toole GA. Microtiter dish biofilm formation assay. J Vis Exp. 2011 Jan 30;(47):2437. doi: 10.3791/2437. PMID: 21307833; PMCID: PMC3182663

3. Sabaeifard P, Abdi-Ali A, Soudi MR, Dinarvand R. Optimization of tetrazolium salt assay for Pseudomonas aeruginosa biofilm using microtiter plate method. J Microbiol Methods. 2014 Oct;105:13440. doi: 10.1016/j.mimet.2014.07.024.

4. Humphries RM, Ambler J, Mitchell SL, Castanheira M, Dingle T, Hindler JA, Koeth L, Sei K; CLSI Methods Development and Standardization Working Group of the Subcommittee on Antimicrobial Susceptibility Testing. CLSI Methods Development and Standardization Working Group Best Practices for Evaluation of Antimicrobial Susceptibility Tests. J Clin Microbiol. 2018 Mar 26;56(4):e01934-17. doi: 10.1128/JCM.01934-17. PMID: 29367292; PMCID: PMC5869819.

Крайникова Д.А.

Внеклеточные метаболиты лактобацилл потенцируют антимикотическое действие флуконазола в отношении Candida albicans в биопленках

Оренбургский федеральный исследовательский центтр УрО РАН (Россия, Оренбург)

doi: 10.18411/lj-04-2021-49

\section{Аннотация}

В настоящем исследовании изучалось влияние нативных метаболитов вагинальных лактобацилл и отдельных их компонентов (пероксид водорода, лактат, сурфактанты) на чувствительность планктонных культур и биопленок Candida albicans к флуконазолу.

Материалы и методы: У 18 клинических изолятов Candida albicans определяли способность образовывать биопленки по связыванию кристаллического фиолетового, чувствительность к флуконазолу методом серийных микроразведений, относительное количество и жизнеспособность грибов в биопленках по восстановлению 3-(4,5диметилтиазол-2-ил)-2,5-дифенил-тетразолий бромида в формазан.

Результаты: Выявлено, что метаболиты лактобацилл повышают чувствительность С. albicans к флуконазолу в биопленках, что сопровождалось уменьшением МИК. Наибольшее влияние на уменьшение минимальной ингибирующей 